\title{
Manajemen Pelatihan Dasar Kepemimpinan Santri dalam Pembentukan Jiwa Kepemimpinan
}

\author{
Ela Nurlela*, \& Dindin Solahudin \\ ${ }^{1}$ Jurusan Manajemen Dakwah, Fakultas Dakwah dan Komunikasi, \\ UIN Sunan Gunung Djati, Bandung \\ *Email : ela.nurlela@gmail.com
}

\begin{abstract}
ABSTRAK
Penelitian ini menjelaskan perencanaan, pengorganisasian, pelaksanaan, pengawasan dan evaluasi Latihan Dasar Kepemimpinan Santri (LDKS) yang dilaksanakan di Pondok Pesantren Al-Ihsan menerapkan prinsip-prinsip dan fungsi manajemen modern. Metode yang digunakan dalam penelitian ini adalah metode deskriptif, untuk menggambarkan dan memberikan penjelasan tentang manajemen Latihan Dasar Kepemimpinan Santri (LDKS) di Pondok Pesantren Al-Ihsan. Penelitian ini menunjukkan bahwa LDKS di Pondok Pesantren AlIhsan sesuai pada prinsip-prinsip manajemen modern sudah terbukti dengan adanya penerapan fungsi-fungsi manajemen modern dalam pelaksanaan LDKS. Penelitian juga menunjukkan bahwa fungsi manajemen telah diterapkan secara teratur dalam kegiatan LDKS di Pesantren Al-Ihsan, karena panitia menerapkan fungsi-fungsi manajemen dalam kegiatan LDKS ini sehingga kegiatan dapat berjalan dengan lancar, sesuai dengan tujuan yang telah di tentukan.
\end{abstract}

Kata Kunci : Manajemen, Kepemimpinan, Santri

\section{ABSTRACT}

This study describes planning, organizing, implementing, monitoring and evaluating the Santri Leadership Basic Training (LDKS) beld at the Al-Ibsan Islamic Boarding School apply the principles and functions of modern management. The method used in this research is descriptive method, to describe and provide an explanation of the management of Santri Leadership Basic Training (LDKS) at Al-Ihsan Islamic Boarding School. This study shows that LDKS in AlIbsan Islamic Boarding School in accordance with the principles of modern management has been proven by the application of modern management functions in the implementation of LDKS. Research also shows that management functions have been applied regularly in LDKS activities at Al-Ihsan Islamic Boarding Schools, because the committee implements management functions in this LDKS activity so that activities can run smoothly, in accordance with the goals that have been set.

Keywords: Management, Leadership, Santri 


\section{PENDAHULUAN}

Islam memandang bahwa ilmu merupakan dasar penentuan martabat dan derajat seseorang dalam kehidupan. Alloh memerintahkan kepada Rasul-Nya untuk senantiasa meminta tambahan ilmu. Dengan bertambahnya ilmu, akan meningkatkan pengetahuan seorang muslim terhadap beberapa dimensi kehidupan baik urusan dunia atau agama. Sehingga ia akan mendekatkan diri dan lebih mengenal Alloh, serta meningkatkan kemampuan dan kompetensinya dalam menjalankan tugas pekerjaan yang dibebankan kepadanya. Pelatihan (training) dalam segala bidang pekerjaan merupakan bentuk ilmu untuk meningkatkan kinerja, dimana islam mendorong umatnya untuk bersungguh-sungguh dan memuliakan pekerjaan. Rasulullah SAW bersabda: “ Tidak ada makanan yang lebih baik yang dimakan oleh seseorang daripada apa yang dia makan dari pekerjaan tangannya. Sesunggubnya Nabi Allob Dawnd a.s memakan makanan dari hasil kerja tangannya."

Islam mendorong untuk melakukan pelatihan (training) terhadap para karyawan dengan tujuan mengembangkan kompetensi dan kemampuan teknis karyawan dalam menuanaikan tanggungjawab pekerjaannya. Rasululloh memberikan pelatihan kepada orang yang diangkat untuk mengurusi persoalan kaum muslimin, dan membekalinya dengan nasihat-nasihat dan beberpa petunjuk (Abu Sinn 2012: 117).

Organisasi santri pesantren Al-Ihsan (OSPAI) merupakan suatu organisasi inti yang ada di pondok pesantren Al-Ihsan yaitu pengurus umum yang mana OSPAI ini terdiri dari OSPAI pusat dan OSPAI wilayah. OSPAI pusat bertanggung jawab atas seluruh santri yang diketuai oleh seorang presiden sedangkan OSPAI wilayah hanya bertanggung jawab di setiap asramnya masingmasing, yang diketuai oleh seorang gubernur. Adapun salah satu agenda yang selalu dilaksanakan oleh menteri pendidikan di Al-Ihsan setiap tahunnya adalah pelatihan dasar kepemimpinan santri, yang mana dalam kegiatan ini santri tidak hanya dibekali dengan materi kepemimpinan islam saja melainkan materi kepemimpinan umum juga di berikan, setelah pemberian materi santri di berikan kesempatan untuk praktek langsung seperti bicara di depan umum yang untuk melatih mental agar berani berbicara di muka umum. Menjadi seorang pemimpin merupakan keharusan bagi setiap manusia, karena latihan kepemimpinan ini tidak hanya untuk berlatih memimpin orang lain ketika kita menjadi seorang manajer atau leader, kita harus bisa memimpin diri sendiri kemana hidup kita akan dibawa itu diri kita yang menentukan.

Pelatihan dasar kepemimpinan santri merupakan sebuah pelatihan dasar tentang segala hal yang berkaitan dengan kepemimpinan pelatihan ini di berikan oleh salah satu bagian dalam OSPAI yaitu menteri pendidikan, pelatihan dasar kepemimpinan yang di berikan ini bertujuan untuk memberikan bekal kepemimpinan kepada seluruh santri baru yang mengikutinya, yang nantinya merupakan salah satu syarat ketika ingin menjadi pemimpin OSPAI ataupun mengikuti organisasi tersebut yaitu harus mempunyai sertifikat Latihan Dasar Kepemimpinan Santri (LDKS). 
Untuk menghindari kesamaan penulisan dan plagiatisme, maka berikut ini penulis sampaikan beberapa hasil penelitian sebelumnya yang memiliki relevansi dengan penelitian ini antara lain sebagai berikut:

Pertama skripsi yang telah di susun oleh Jejen Jalaludin: 2006 dengan judul "Manajemen Pelatihan Kegiatan Syahril Qur'an (UPTQ) UKM UIN Sunan Gunung Djati Bandung “ skripsi ini menjelaskan bahwa UPTQ UIN Sunan Gunung Djati Bandung sudah berusaha menyelenggarakan pelatihan syarhil Qur'an debaik mungkin dengan menerapkan fungsi-fungsi manajemen pelatihan syarhil qur'an, selain itu di lihat dari hasilnya UPTQ telah memberikan kontribusi positif pada proses pelatihan syarhil Qur'an. Hal ini terlihat dengan seringnya menjadi juara dalam musabaqoh tilawatil Qur'an baik di tingkat local maupun nasional serta dengan maraknya gerakan dakwah di pelosok daerah. Bahwa untuk mencapai pelatihan syarhil Qur'an yang efektif dan efisien serta untuk meningkatkan kemampuan dan keterampilan kualitas para kader atau tenaga pelaksana syahril Qur'an dibutuhkan peran manajemen secara optimal yang dilakukan dengan sistematis dan penuh tanggungjawab.

Penelitian ini bertujuan untuk mengetahui proses manajemen dalam melaksanakan pelatihan kegiatan Syahril Qur'an dengan melakukan fungsi-fungsi manajemen yang meliputi perencanaan (planning) pengorganisasian (organizing) penggerakan (actuating) dan pengawasan (controlling) syahril Qur'an di UPTQ UIN Sunan Gunung Djati Bandung.

Metode penelitian yang digunakan adalah metode deskriptif yaitu metode yang mendeskripsikan atau menganalisis suatu hasil penelitian tapi tidak digunakan untuk membuat kesimpulan secara lebih luas . Adapun pendapat lain menyatakan bahwa metode deskriptif adalah metode penelitian yang berusaha mendeskripsikan gejala, peristiwa, kejadian yang terjadi pada saat sekarang.

Ini dimaksudkan untuk menggambarkan, memaparkan dan menjelaskan data-data suatu informasi tentang manajemen pelatihan dasar kepemimpinan santri di pondok pesantren Al-ihsan dalam memebentuk jiwa kepemimpinan melalui wawancara, observasi dan studi kepustakaan secara menyeluruh terhadap objek penelitian. Kemudian dari data yang telah di peroleh dan terkumpul maka dilakukan analisis, dengan menggunakan metode deskriptif yang dapat membantu peneliti mendapatkan data yang akurat, benar dan lengkap berdasarkan data yang telah di kumpulkan dan di kelola secara sistematis.

Istilah manajemen berasal dari bahasa Perancis kuno menagement, yang artinya seni melaksanakan dan mengatur. Manajemen belum memiliki definisi yang mapan dan diterima secara universal. Marry Parker Follet, misalnya, mendefinisikan manajemen sebagai seni menyelesaikan pekerjaan melalui oranglain. Definisi ini berarti bahwa seorang manajer bertugas mengatur dan mengarahkan oranglain untuk mencapai tujuan organisasi. Ricky W griffin dalam Endin Nasrudin (2010:21) mendefinisikan manajemen sebagai sebuah proses perencanaan, pengorganisasian, pengkoordinasian, dan pengontrolan sumberdaya untuk mencapai sasaran secara efektif dan efisien. Efektif berarti tujuan dapat dicapai sesuai dengan perencanaan, sedangkan efisiensi berarti tugas yang yang dilaksanakan secara benar, terorganisir, dan sesuai jadwal (Endin Nasrudin, 2010: 21).

Secara etimologis, kata manajemen berasal dari bahas inggris yaitu management yang berarti ketatalaksanaan, tata pimpinan, dan pengelolaan. Artinya manajemen adalah sebagai suatu proses yang di terapkan oleh individu atau kelompok dalam upaya-upaya koordinasi untuk mencapai suatu tujuan. Secara terminologi manajemen adalah sebuah proses perencanaan, pengorganisasian, pengaturan terhadap para anggota organisasi serta 
penggunaan seluruh sumber-sumber yang ada secara tepat untuk meraih tujuan organisasi yang telah di tetapkan. Robert Kritiner mendefinisikan manajemen sebagai suatu proses kerja melalui oranglain untuk mencapai tujuan organisasi dalam lingkungan yang berubah proses ini berpusat pada penggunaan yang efektif dan efisien terhadap penggunaan sumberdaya manusia (M. Munir dan wahyu Ilaihi, 2006: 9-10).

Dale Yoder dalam Aep Kusnawan (2009:8) mengemukakan pelatihan berarti pengembangan tenaga kerja untuk pekerjaan-pekerjaan tertentu. Sementara John H. Proctor dan William M. thornton dalam Aep Kusnwan (2009:8) mengemukakan rumusan pelatihan sebagai tindakan yang di sengaja untuk memberikan alat agar belajar dapat dilaksanakan. Rumusan lainnya dari Edwin B Floppo, bahwa latihan adalah proses membantu pegawai untuk memperoleh efektivitas dalam pekerjaa mereka yang sekarang atau yang akan datang melalui pengembangan kebiasaan pikiran dan tindakan, kecakapan, pengetahuan dan sikap. Hisyam ath-Thalib dalam Aep Kusnawan (200:9) mengemukakan latihan sebagai rangkaian program dan pelaksanaan yang berhubungan dengan ilmu pengetahuan dan memperbaiki keterampilan atau kemampuan berbuat sebagaimana yang di harapkan.

Sedangkan kepemimpinan adalah salah satu aspek yang paling penting dari studi perilaku keorganisasian manusia. Ini adalah pemimpin yang menciptakan lingkungan kerja keberhasilan suatu organisasi tergantung pada efisiensi pemimpin ini adalah atribut pendekatan positif dan kemampuan untuk memecahkan seorang pimpinan. Kepemimpinan dapat juga di definisikan sebagai pengaruh atau proses mempengaruhi seseorang sehingga mereka akan berusaha rela dan antusias terhadap tujuan prestasi suatu kelompok (V.G Kondalkar 2007:224-225).

Carlyle dalam essay-nya yang di kutip oleh Mar'at (1984: 7) tentang para pahlawan mengonsepsikan pemimpin sebagai seorang individu yang memiliki bakat bawaan yang di peroleh dari keturunan yang khas. Pemimpin dan kepemimpinan merupakan suatu kesatuan kata yang tidak dapat di pisahkan secara struktural maupun fungsional. Kepemimpinan merupakan konsep yang berdasarkan pengalaman, arti ketua atau raja dapat ditemukan dalam beberapa bahasa hanyalah untuk menunjukkan adanya pembedaan antara pemerintah dari anggota masyarakat lainnya (Mar'at, 1984: 7-8).

Jhon F dan Robert B dalam bukunya public management yang di kutip oleh Abu Sinn (2012:128) memberikan definisi kepemimpinan sebagai seni untuk mengatur individu dan masyarakat, serta memotivasi semangat mereka untuk meraih tujuan yang telah di tetapkan. Menurut Arted kepemimpinan adalah kemampuan untuk memengaruhi orang lain agar mereka berusaha membantu untuk mewujudkan tujuan yang diimpikan bersama. Jhon B memberikan definisi kepemimpinan sebagai kegiatan atau proses untuk saling mempengaruhi antar individu yang tergabung dalam satu kelompok walaupun ada perbedaan diantara mereka untuk diarahkan pada kegiatan kemanusiaan berdasarkan permasalahan bersama (Ibrahim Abu Sinn,2012:128).

\section{LANDASAN TEORITIS}

Manajemen adalah suatu proses atau kerangka kerja, yang melibatkan bimbingan atau pengarahan suatu kelompok orang-orang kearah tujuan-tujuan organisasional atau maksud-maksud yang nyata. Manajemen adalah suatu kegiatan, pelaksanaannya adalah managing, pengelolaan, sedang pelaksanaannya disebut manager atau pengelola. Manajemen adalah ilmu pengetahuan maupun seni. Ada 
suatu pertumbuhan yang teratur mengenai manajemen suatu ilmu pengetahuan yang menjelaskan manajemen dengan pengacuan kepada kebenaran-kebenaran umum (Terry dan Rue, 1-2:2015).

Menurut Parker (Stoner dan Freeman,2000) dalam Brantas (2009:4) Manajemen adalah seni melaksanakan pekerjaan melalui orang-orang (the art of getting things done through people). Terlepas dari segi mana para ahli itu memandang manajemen dan mengemukakan definisinya, pada hakikatnya setiap definisi itu mengandung dasar falsafah dan unsur-unsur yang bersamaan yang terletak pada: Di dalam manajemen terdapat tujuan yang ingin di capai yang telah di tetapkan terlebih dahulu (adanya predetermind objectives), Dalam pencapaian tujuan tersebut manajer tidak selalu mengerjakan sendiri tetapi melalui pendelegasian wewenang. Kegiatan dilakukan oleh para bawahan berdasarkan hierarki organisasi dengan mempergunakan orang-orang atau pegawai (kegiatan dilakukan through the effort of the people), Dalam proses pencapaian tujuan dilakukan fungsi-fungsi perencanaan, pengorganisasian, pengarahan, bimbingan dan pengawasan sehingga penggunaan factor-faktor human dan non human dapat dilaksanakan secara efektif dan efisien (how to manage of effectivelly) (Brantas, 4-8: 2009).

Dale Yoder dalam Aep Kusnawan dan Aep Sy Firdaus (2009:6) mengemukakan pelatihan berarti pengembangan tenaga kerja untuk pekerjaanpekerjaan tertentu. Sementara John H. Proctor dan William M. Thornton yang dikutip oleh Aep Kusnawan dan Aep Sy Firdaus (2009:6) mengemukakan rumusan pelatihan sebagai tindakan yang di sengaja untuk memberikan alat agar belajar dapat dilaksanakan. Rumusan lainnya dari Edwin B Floppo, dalam Aep Kusnawan dan Aep Sy Firdaus (2009:7) bahwa latihan adalah proses membantu pegawai untuk memperoleh efektivitas dalam pekerjaa mereka yang sekarang atau yang akan datang melalui pengembangan kebiasaan pikiran dan tindakan, kecakapan, pengetahuan dan sikap. Hisyam ath-Thalib dalam Aep Kusnawan dan Aep Sy Firdaus (2009:8) mengemukakan latihan sebagai rangkaian program dan pelaksanaan yang berhubungan dengan ilmu pengetahuan dan memperbaiki keterampilan atau kemampun berbuat sebagaimana yang di harapkan.

Dengan pengertian tersebut, dapat di tarik suatu makna bahwa, suatu kegiatan pelatihan hendaknya mencakup syarat: Pelatihan harus membantu seseorang menambah kemampuannya, Latihan harus menimbulkan perubahan dalam kebiasaan bekerja seseorang. Dalam sikapnya terhadap suatu pekerjaan, dalam informasi dan pengetahuan yang ia terapkan dalam pekerjaan sehari-hari, Latihan harus berkaitan dengan pekerjaan tertentu seseorang dapat ikut mengambil bagian dalam berbagai program pelatihan yang berbeda, karena spesifikasi yang berbeda pula (Aep Kusnawan dan Aep Sy Firdaus, 2009: 6-10)

Tujuan utama pelatihan dan pengembangan pada intinya dapat dikelompokkan dalam enam bidang utama yaitu: Memperbaiki kinerja, Memutakhirkan keahlian, Mengurangi waktu belajar bagi karyawan baru supaya menjadi kompeten dalam pekerjaannya, Membantu memecahkan masalah 
operasional, Memenuhi kebutuhan-kebutuhan perkembangan pribadi, Memepersiapkan karyawan untuk promosi (Meldona, 2009:231-236).

Kepemimpinan adalah salah satu aspek yang paling penting dari studi perilaku keorganisasian manusia. Ini adalah pemimpin yang menciptakan lingkungan kerja keberhasilan suatu organisasi tergantung pada efisiensi pemimpin ini adalah atribut pendekatan positif dan kemampuan untuk memecahkan seorang pimpinan. Kepemimpinan dapat juga di definisikan sebagai pengaruh atau proses mempengaruhi seseorang sehingga mereka akan berusaha rela dan antusias terhadap tujuan prestasi suatu kelompok (V.G Kondalkar, 2007:224-225).

Reuteur" Leadership ps an ability to persuade or direct men without use of the prestige or power of formal office or external circumstance" (Kepemimpinan adalah suatu kemampuanuntuk mengajak atau mengarahkan orang-orang tanpa memakai perbawa atau kekuatan formal jabatan atau keadaan luar).

G. L. Freeman dan E.K Taylor" Leadership is the ability to create group action toward an organizational objective with maximum effectiveness and cooperation from each individual." (Kepemimpinan adalah kemampuan untuk menciptakan kegiatan kelompok mencapai tujuan organisasi dengan efektivitas maksimum dan kerjasama dari tiap-tiap individu).

Santri merupakan peserta didik atau objek pendidikan, tetapi di beberapa pesantren, santri yang memiliki kelebihan potensi intelektual (santri senior) sekaligus merangkap tugas mengajar santri-santri junior. Adapun kebiasaan para santri yang selalu memberikan penghormatan yang terkadang berlebihan kepada kiainya, kebiasaan ini menjadikan santri sangat pasifkarena khawatir kehilangan barokah. Kekhawatiran ini menjadi salah satu sikap yang khas pada santri dan cukup membedakan dengan kebiasaan yang dilakukan siswa siswi sekolah maupun siswa siswi lembaga kursus. Akan tetapi belakangan ini ada perkembangan baru di kalangan santri. Hasan melukiskan bahwa dulu semangat rukhiyahnya semangat mendengar dan patuh pada kiai dan guru masih tinggi sedangkan sekarang yang terjadi adalah semangat rub-al-intiqaa (sikap kritis mempertanyakan). Jika pada awal pertumbuhan pesantren dulu santri tidak berani berbicara sambil menatap mata kiai, maka sekarang telah terlibat diskusi atau dialog dengan kiai mengenai berbagai masalah (Mujamil Qomar 2002:17-21).

Adapun Fungsi-fungsi Manajemen yang harus diperhatikan antara lain: pertama, Perencanaan (Planning). Perencanaan meliputi tindakan memilih dan menghubungkan fakta-fakta dan membuat serta menggunakan asumsi-asumsi mengenai masa yang akan datang dalam hal memvisualisasi serta merumuskan aktivitas-aktivitas yang diusulkan yang dianggap perlu untuk mencapai hasil-hasil yang diinginkan. Ada macam-macam keuntungan yang berkaitan dengan perencanaan formal yang dapat menyebabkan para manajer pada semua tingkat sesuatu organisasi mengerahkan lebih banyak waktu dan upaya sehubungan dengan fungsi manajemen primer ini. Perencanaan dapat menyebabkan: Timbulnya aktivitas-aktivitas teratur yang di tujukan kearah pencapaian sasaran, 
Perencanaan menunjukkan perlu diadakannya perubahan pada masa yang akan datang, Perencanaan memberikan sebuah dasar atau landasan untuk melakukan pengawasan, Perencanaan mendorong orang memberikan prestasi, Perencanaan memaksakan orang untuk memandang perusahaan secara menyeluruh, Perencanaaan membesar dan mengimbangkan pemanfaatan fasilitas-fasilitas, Perencanaan membenatu seorang manajer mencapai status (George Terry Wihardy,1986:163-166).

Harold Koontz dan Cyril O'Donel mengungkapkan bahwa Planning is the function of a manager which involves the selection from alternatives of objectives, policies, procedures and programs Perencanaan adalah fungsi seorang manajer yang berhubungan dengan memilih tujuan-tujuan, kebijaksanaan-kebijaksanaan, prosedur-prosedur, program-program dan alternatif yang ada (Malayu S.P Hasibuan, 2001; 40). Langkah-langkah perencanaan menurut George Terry adalah sebagai berikut: Jelaskan problem yang bersangkutan, Usahakanlah untuk mencapai keterangan-keterangan tentang aktivitas-aktivitas yang dilaksanakan, Analisislah dan klasifikasikanlah keterangan-keterangan yang di peroleh, Tetapkanlah premis-premis perencanaan dan penghalangan-penghalangan terhadapnya, Tentukan rencana-rencana alternatif, Pilihlah rencana yang diusulkan, Tetapkanlah urutan-urutan dan penetapan waktu secara terperinci bagi rencana, Laksanakanlah pengecekan tentang kemajuan rencana yang diusulkan.

Kelemahan-kelemahan dari perencanaan diantaranya; Karena planning berhubungan dengan masa yang akan datang, maka tidak dapat menentukan terjadinya sesuatu itu dengan pasti. Kadang-kadang planning yang di dahului dengan suatu riset yang mendalam membutuhkan biaya yang besar. Penghalangpenghalang psikologis dimana orang sering memperhatikan kebutuhan masa sekarang lebih berharga daripada masa yang akan datang. Ada orang yang mengintrepretasikan, planning merupakan suatu cara kerja dengan paksaan tentang apa yang telah digariskan. Sering orang-orang lebih menitikberatkan perhatian pada maslah-masalah yang dihadapi menurut kenyataan yang harus dilaksanaku sama lain dipengaruhi dari pada pemikiran masalah yang membutuhkan pemikiran yang jelas (Brantas, 55-68: 2009).

Kedua, Pengorganisasian (Organizing). Pengorganisasian mempersatukan orang-orang pada tugas yang saling berkaitan istilah pengorganisasian berasal dari perkataan organism (organisme) yang merupakan sebuah entitas dengan bagianbagian yang terintegrasi demikian rupa hingga hubungan mereka satu sama lain dipengaruhi oleh hubungan mereka terhadap keseluruhan. Pengorganisasian adalah tindakan mengusahakan hubungan-hubungan kelakuan yang efektif antara orang-orang, hingga mereka dapat bekerja sama secara effisien dan demikian memperoleh kepuasan pribadi dalam melaksanakan tugas-tugas tertentu dalam kondisi lingkungan tertentu guna mencapai tujuan atau sasaran tertentu (Terry dan Winardi, 233-234: 1986). Langkah- langkah yang dapat dilakukan dalam pengorganisasian adalah sebagai berikut: Manajer harus mengetahui tujuan organisasi yang ingin dicapai, apakah profit motive atau service motive, Penentuan 
kegiatan-kegiatan, artinya manajer harus mengetahui, merumuskan, dan menspesifikasikan kegiatan-kegiatan yang diperlukan untuk mencapai tujuan organisasi dan menyusun daftar kegiatan-kegiatan yang akan dilakukan, Pengelompokkan kegiatan-kegiatan, artinya manajer harus mengelompokkan kegiatan-kegiatan ke dalam beberapa kelompok atas dasar tujuan yang sama. Kegiatan-kegiatan yang bersamaan dan berkaitan erat disatukan kedalam satu departemen atau satu bagian, Pendelegasian wewenang, artinya manajer harus menetapkan besarnya wewenang yang akan di delegasikan kepada setiap departemen, Rentang kendali, artinya manajer harus menetapkan jumlah karyawan pada setiap departemen atau bagian, Peranan perorangan, artinya manajer harus menetapkan dengan jelas tugas-tugas setiap individu karyawan, supaya tumpang tindih tugas dihindarkan, Tipe organisasi, artinya manajer harus menetapkan tipe organisasi apa yang akan dipakai, apakah line organization, line and staff organization ataukah function organization, Struktur (organization chart=bagan organisasi), artinya manajer harus menetapkan struktur organisasi yang bagaimana yang akan di pergunakan, apa struktur organisasi segi tiga vertikal, segi tiga horizontal, berbentuk lingkaran, berbentuk setengah lingkaran, berbentuk kerucut vertikal/ horizontal ataukah bentuk oval (Brantas, 69-85:2009).

Ketiga, Pelaksanaan (actuating). merupakan usaha untuk menggerakkan anggota-anggota kelompok demikian rupa hingga mereka berkeinginan dan berusaha untuk mencapai sasaran-sasaran perusahaan yang bersangkutan dan sasaran-sasaran anggota perusahaan tersebut oleh karena para anggota itu ingin mencapai sasaran-sasaran tersebut. Pada dasarnya actuating dimulai dalam diri kita sendiri dan bukan menggerakkan pihak lain, guna mencapai sukses terbesar dalam bidang actuating senantiasa harus bersifat objektif dalam penentuan serta penggunaannya, usaha actuating sangat bersifat pribadi dan disinilah terletak bagian terbesar daripada tantangan (Terry dan Winardi, 313-314: 1986).

Keempat, Pengawasan dan Evaluasi (controlling dan evaluating). Pengawasan secara umum dapat di definisikan sebagai cara suatu organisasi mewujudkan kinerja yang efektif dan efisien, serta lebih jauh mendukung terwujudnya visi dan misi organisasi. G.R Terry controlling can be defined as the process of determining what is to be accomplished that the standard, what is being accomplished, that is the performance, evaluating the performance take place according to plans, that is, in conformity, with the standard (Pengawasan dapat di definisikan sebagai proses penentuan apa yang harus dicapai yaitu standard apa yang sedang dilakukan yaitu pelaksanaan, menilai pelaksanaan dan apabila perlu dilakukan perbaikan-perbaikan, sehingga pelaksanaan sesuai dengan rencana, yaitu selaras dengan standard).

Secara umum ada beberepa manfaat yang di peroleh dengan di berlakukannya pengawasan pada suatu organisasi yaitu: Pengawasan memiliki peran penting terutama dalam memastikan setiap pekerjaan terlaksana sesuai dengan yang di rencanakan, Disamping itu pengawasan juga memiliki peran dalam membantu manajer dalam mengawal dan mewujudkan visi misi perusahaan, Pengawasan bernilai positif dalam membangun hubungan yang baik antara 
pimpinan dan karyawan, Pengawasan yang baik memiliki peran dalam menumbuh kembangkan keyakinan para stakeholders pada organisasi.

Ada beberapa tipe pengawasan menurut T. Hani Handoko diantaranya: Pengawasan pendahuluan, Pengawasan concurrent, Pengawasan umpan balik

Secara umum ada beberapa alasan mengapa dalam suatu organisasi diperlukan pengawasan, yaitu: Agar kualitas output yang dihasilkan menjadi lebih baik dan sesuai dengan keinginan banyak pihak, khususnya pengguna produk, Terbentuknya konsep manajemen sesuai dengan yang diinginkan pihak komisaris yang diinginkan oleh pihak komisaris perusahaan menginginkan perolehan dividen tahun ini adalah 12 persen, maka karena pengawasan yang dilakukan perusahaan maka akhirnya target 12 persen tersebut tercapai, Dengan adanya pengawasan maksimal diharapkan tujuan dan keinginan terbentuknya Good Corporate Governance (GCG) akan dapat diwujudkan. Pembentukan GCG lebih jauh telah memposisikan terwujudnya organisasi yang bersih (clean organization) dan manajemen profesional (Irham Fahmi, 2012:84-87).

Kepemimpinan merupakan salah satu aspek manajerial dalam kehidupan organisasi yang berada pada posisi kunci dalam menggerakan seluruh potensi yang ada. Karena itu kepemimpinan akan mampu membedakan suatu organisasi dengan organisasi yang lainnya (Jamal Lulai Yunus, 2009:22).

Kepemimpinan adalah suatu seni kesanggupan atau teknik untuk membuat sekelompok orang dalam organisasi formal atau para pengikut atau simpatisan dalam organisasi yang informal mengikuti dan mentaati segala apa yang dikehendaki, membuat mereka begitu antusias atau bersemangat untuk mengikutinya, bahkan ada yang sanggup berkorban (M. Karjadi, 1989: 2-3).

Tipe kepemimpinan dapat diartikan sebagai bentuk atau pola atau jenis kepemimpinan yang di dalamnya di implementasikan satu atau lebih perilaku atau gaya kepemimpianan sebagai pendukungnya. Sedang gaya kepemimpinan diartikan sebagai perilaku atau cara yang di pilih dan di pergunakan pimpinan dalam memepengaruhi pikiran, perasaan, sikap dan perilaku para anggota organisasi (Hadari Nawawi, 2006:115-116).

Sondang P Siagian (2010:27) menyatakan meskipun belum terdapat kesepakatan bulat tentang tipologi kepemimpinan yang dikenal secara luas dewasa in, lima tipe kepemimpinan yang diakui keberadaannya adalah: Tipe yang otokratik Seorang pemimpin yang otokratik adalah seorang pemimpin yang sangat egois, Tipe yang paternalistik Tipe pemimpin yang paternalistik banyak terdapat di lingkungan masyarakat yang masih bersifat tradisional, umumnya di masyarakat yang agraris. Popularitas pemimpin yang paternalistik akan bertindak sendiri, Tipe yang kharismatik Seorang pemimpin yang kharismatik adalah seorang yang dikagumi oleh banyak pengikut meskipun para pengikut tersebut tidak selalu dapat menjelaskan secara konkret mengapa orang tersebut di kagumi, Tipe yang laissez faire Seorang pemimpin yang laissez faire cenderung memilih peranan yang pasif dan membiarkan organisasi berjalan menurut temponya sendiri tanpa banyak mencampuri bagaimana organisasi harus dijalankan dan di 
gerakkan, Tipe yang demokratik Pemimpin yang demokratik dipandang sebagai pemimpin yang paling ideal, diakui bahwa pemimpin yang demokratik tidak selalu merupakan pemimpin yang efektif dalam kehidupan oragnisasional (Sondang $\mathrm{P}$ Siagian,2010: 27-43).

Adapau ciri kepemimpinan yang dikemukan oleh George R. Terry dalam Irham Fahmi (2012:61) mengemukakan delapan dari ciri pemimpin diantaranya: Energi, mempunyai kekuatan mental dan fisik, Stabilitas emosi, seorang pemimpin tidak boleh berprasangka jelek terhadap bawahannya, ia tidak boleh cepat marah dan percaya pada diri sendiri harus cukup sabar, Human relationship, mempunyai pengetahuan tentang hubungan manusia, Personal motivation, keinginan untuk menjadi pemimpin harus besar, dan dapat memotivasi diri sendiri, Comunication skill, mempunyai kecakapan berkomunikasi, Teaching skill, mempunyai kecakapan untuk mengajarkan, menjelaskan dan mengembangkan bawahannya, Social skill, mempunyai keahlian di bidang sosial, supaya terjamin kepercayaan dan kesetiaan bawahannya. Ia harus suka menolong, senang jika bawahannya maju, peramah serta luwes dalam pergaulan, Technical competent, mempunyai kecakapan menganalisis, merencanakan,mengorganisasi,mendelegasikan wewenang, mengambil keputusan dan mampu menyusun konsep (Irham Fahmi, 2012:60-61).

\section{HASIL DAN PEMBAHASAN}

Dalam manajemen terdapat fungsi-fungsi yang harus dijalankan dalam setiap kegiatan untuk mencapai hasil yang telah di tetapkan, berikut fungsi-fungsi manajemen yang dilakukan dalam pelaksanaan LDKS di Pondok Pesantren AlIhsan diantaranya: Perencanaan pelatihan dasar, pengorganisasian, pelaksanaan, dan pengawasan pelatihan dasar kepemimpinan santri.

\section{Perencanaan Pelatihan Dasar Kepemimpinan Santri}

Perencanaan (planning) adalah fungsi dasar atau fungsi fundamental manajemen, karena organizing, actuating, dan controlling pun harus terlebih dahulu di rencanakan. Perencanaan di tujukan pada masa depan yang penuh dengan ketidakpastian. Dampak perencanaan baru akan terasa pada masa yang akan datang, agar resiko yang di tanggung relative kecil hendaknya segala kegiatan, tindakan, kebijaksanaan direncanakan terlebih dahulu. Perencanaan adalah kumpulan keputusankeputusan. Planning adalah suatu proses untuk menentukan (plan) dengan kata lain perencanaan di proses oleh perencana (planer) dan hasilnya adalah rencana (plan) (Malayu S.P Hasibuan, 2001;40), Perenecanaan berarti menentukan sebelumnya apa yang harus dilakukan dan bagaiman cara melakukannya. Perencanaan dapat dianggap sebagai suatu kumpulan keputusan-keputusan, dalam hubungan mana perencanaan tersebut dianggap sebagai tindakan mempersiapkan tindakantindakan untuk masa yang akan datang dengan jalan membuat keputusankeputusan sekarang.

Ada macam-macam keuntungan yang berkaitan dengan perencanaan formal yang dapat menyebabkan para manajer pada semua tingkat sesuatu 
organisasi mengerahkan lebih banyak waktu dan upaya sehubungan dengan fungsi manajemen primer ini.

Dari hasil wawancara dengan presiden OSPAI, dalam setiap kegiatan selalu ada perencanaan untuk mencapai tujuan bersama, begitupun dalam pelatihan dasar kepemimpinan santri di Pondok Pesantren Al-Ihsan di rencanakan berdasarkan hasil rapat semua pengurus, dalam rapat pertama di hadiri oleh 16 orang yang mana di pimpin oleh presiden dan di hadiri oleh menteri-menteri dan sekretarisnya, dalam rapat tersebut membicarakan program tahunan yang biasa di selenggarakan oleh menteri pendidikan. Setelah rapat perencanaan pelaksanaan LDKS lalu menteri pendidikan membentuk panitia pelaksana, untuk pemilihan ketua pelaksana menteri pendidikan langsung menunjuk salah satu staf Kementrian Pendidikan, setelah terpilihnya ketua pelaksana maka, satu bulan sebelum acara presiden meng-SK kan panitia LDKS (Latihan Dasar Kepemimpinan Santri).

Jadi menurut pendapat saya dari perencanaan LDKS di atas dapat di simpulkan bahwa setiap bagian dalam kepanitiaan LDKS ini di haruskan untuk bertanggungjawab atas semua tugas yang telah di berikan kepada mereka, untuk mempermudah dalam berlangsungnya acara dan dapat mencapai tujuan yang telah di tentukan sejak awal. Perencanaan dalam kegiatan LDKS ini merupakan tahap awal bagi panitia dalam persiapan pelaksanaan LDKS untuk tercapainya tujuantujuan di selenggarakannya LDKS ini.

\section{Pengorganisasian Pelatihan Dasar Kepemimpinan Santri}

Pengorganisasian merupakan sebuah kasus dimana berbeda halnya dengan ilmu pasti dasar jumlahnya adalah lebih besar dibandingkan dengan jumlah bagianbagian individualnya. Pengorganisasian dapat menimbulkan effek yang sangat baik atas usaha menggerakkan dan pengawasan manajerial (Terry dan Winardi, 233-234: 1986). Mengorganisasi adalah proses pengelompokan kegiatan-kegiatan untuk mencapai tujuan-tujuan dan penugasan setiap kelompok kepada soorang manajer yang mempunyai kekuasaan yang perlu untuk mengawasi anggotaanggota kelompok. Pengorganisasian dilakukan untuk menghimpun dan mengatur semua sumber-sumber yang diperlukan, termasuk manusia, sehingga pekerjaan yang di kehendaki dapat dilaksanakan dengan berhasil baik.

Pengorganisasian menurut Usman, Husaini dalam Handoko (2006) adalah penentuan sumberdaya dan kegiatan yang dibutuhkan untuk mencapai tujuan organisasi, proses perancangan dan pengembangan suatu, organisasi yang akan dapat membawa hal-hal tersebut kearah tujuan, pendelegasian wewenang yang diperlukan kepada individu-individu umtuk melaksanakan tugas-tugasnya. Ditambahkan pula oleh Handoko pengorganisasian ialah pengaturan kerjasama sumberdaya keuangan, fisik dan manusia dalam organisasi. Pengorganisasian merupakan penyusunan struktur organisasi yang sesuai dengan tujuan organisasi, sumber daya yang dimilikinya, dan lingkungannya yang melingkupinya. 
Istilah pengorganisasian menurut Handoko (2003) adalah cara manajemen merancang struktur formal untuk penggunaan yang paling efektif terhadap sumber daya keuangan, fisik bahan baku, dan tenaga kerja organisasi. Bagaiman organisasi mengelompokkan kegiatannya, dimana setiap pengelompokan diikuti penugasan seorang manajer yang diberi wewenang mengawasi anggota kelompok. Hubungan antara fungsi, jabatan, tugas karyawan. Cara manajer membagi tugas yang harus dilaksanakan dalam departemen dan mendelegasikan wewenang untuk mengerjakan tugas tersebut. Pada dasarnya mengorganisir adalah suatu proses pembagian kerja.

Pengorganisasian yang dilakukan dalam pemilihan panitia LDKS (latihan Dasar Kepemimpinan Santri) dengan cara merekrut para santri dari tiap asrama, ada yang di tunjuk langsung oleh ketua pelaksana dan ada yang mangajukan diri, untuk yang di tunjuk langsung oleh ketua pelaksana mereka akan diberi surat kesediaan untuk menjadi panitia pelaksana dan siap untuk bekerjasama dari awal sampai akhir kepanitiaan. Sedangkan untuk para santri yang mengajukan diri untuk menjadi panitia LDKS (Latihan Dasar Kepemimpinan Santri) mereka harus sudah mengikuti LDKS sebelumnya yang dibuktikan dengan adanya sertifikat dan pernah menjadi panitia dalam berbagai kegiatan yang terselenggara di pondok pesantren al-ihsan, selain itu mereka diwawancara dan di uji kelayakan oleh Menteri Pendidikan dan Ketua Pelaksana yang telah terpilih (Hasil wawancara dengan Presiden OSPAI).

Dapat disimpulkan dari pengorganisasian pembentukan panitia LDKS ini bahwa semua santri berhak untuk menjadi panitia dalam pelaksanaan LDKS akan tetapi santri yang dipilih untuk menjadi panitia LDKS ini merupakan santri yang aktif dan selalu mengikuti kegiatan yang di selenggarakan di Pondok Pesantren Al-Ihsan. Akan tetapi tidak adil halnya jika panitia hanya di tetntukan atau di pilih oleh menteri pendidikan saja maka di bukalah pengrekrutan untuk menjadi panitia LDKS yang mana bagi setiap santri yang ingin menjadi panitia LDKS bisa mendaftar kepada staf kementrian pendidikan dan harus memenuhi syarat-syarat yang telah di tentukan.

\section{Pelaksanaan Pelatihan Dasar Kepemimpinan Santri}

Pelaksanaan (Actuating) merupakan usaha untuk menggerakkan anggota-anggota kelompok demikian rupa hingga mereka berkeinginan dan berusaha untuk mencapai sasaran-sasaran perusahaan yang bersangkutan dan sasaran-sasaran anggota perusahaan tersebut oleh karena para anggota itu ingin mencapai sasaransasaran tersebut. Hal dasar bagi tindakan menggerakkan adalah manajemen yang berpandangan progresif maksudnya para manajer harus menunjukkan melalui kelakuan dan keputusan-keputusan mereka bahwa mereka mempunyai perhatian yang dalam untuk anggota-anggota organisasi mereka. Pada dasarnya actuating dimulai dalam diri kita sendiri dan bukan menggerakkan pihak lain, guna mencapai sukses terbesar dalam bidang actuating senantiasa harus bersifat objektif dalam penentuan serta penggunaannya, usaha actuating sangat bersifat pribadi dan 
disinilah terletak bagian terbesar daripada tantangan (Terry dan Winardi, 313-314: 1986). Penggerakan adalah hubungan antara aspek-aspek individual yang di timbulkan oleh adanya pengaturan terhadap bawahan-bawahan untuk dapat di mengerti dan pembagian pekerjaan yang efektif dan efisian untuk tujuan perusahaan yang nyata. Jadi, penggerakan adalah kegiatan yang dilakukan oleh pimpinan untuk membimbing, mengarahkan, mengatur segala kegiatan yang telah di beri tugas dalam melaksanakan suatu kegiatan usaha. Agar proses penggerakan berjalan efektif, merupakan suatu keharusan bagi seorang manajer untuk memahami perilaku manusia, sehingga dapat memimpin organisasi dengan baik, menjalankan komunikasi dengan efektif, dapat memberikan motivasi yang tepat serta dapat menciptakan hubungan yang harmonis dengan bawahan (Brantas, 9495:2009).

Pelaksanaan (Actuating) merupakan usaha untuk menggerakkan anggotaanggota kelompok demikian rupa hingga mereka berkeinginan dan berusaha untuk mencapai sasaran-sasaran perusahaan yang bersangkutan dan sasaransasaran anggota perusahaan tersebut oleh karena para anggota itu ingin mencapai sasaran-sasaran tersebut. Hal dasar bagi tindakan menggerakkan adalah manajemen yang berpandangan progresif maksudnya para manajer harus menunjukkan melalui kelakuan dan keputusan-keputusan mereka bahwa mereka mempunyai perhatian yang dalam untuk anggota-anggota organisasi mereka. Pada dasarnya actuating dimulai dalam diri kita sendiri dan bukan menggerakkan pihak lain, guna mencapai sukses terbesar dalam bidang actuating senantiasa harus bersifat objektif dalam penentuan serta penggunaannya, usaha actuating sangat bersifat pribadi dan disinilah terletak bagian terbesar daripada tantangan (Terry dan Winardi, 313-314: 1986).

Di dalam acara LDKS ini hari pertama di hadiri oleh peserta dengan jumlah 120 di hadiri oleh pengurus OSPAI dan pimpinan pesantren, dan di hari pertama pula panitia memberikan kontrak belajar yang harus di patuhi selama kegiatan LDKS berlangsung, dan materi yang di sampaikan pada hari pertama yaitu, Peranan santri, agama, dan peradaban dengan pemateri Ust Nurhasan, dan materi kedua Manajemen organisasi oleh Kang Nuhas. Hari kedua LDKS di hadiri oleh peserta dengan jumlah 115 dengan materi Public speaking oleh Ust. Ramdan Juniarsah, Kepemimpinan ideal oleh KH.Dindin Solahudin dan Problem solving oleh Ust. Ucup Fathudin Alma'arif. Hari ketiga dihadiri oleh peserta dengan jumlah 118 dengan materi terahir yaitu Persidangan dan simulasi oleh Manarul Hidayat dan di bantu oleh seluruh panitia (Hasil wawancara dengan Presiden OSPAI).

Dari pelaksanaan LDKS ini dapat saya simpulkan bahwa kegiatan ini merupakan program tahunan yang wajib diikuti oleh setiap santri baru untuk pengkaderan pemimpin atau untuk menyiapkan santri dan santriwati yang siap menjadi pemimpin di kemudian hari, dengan waktu pelaksanaannya selama tiga hari dan dalam tiga hari tersebut dua hari pertama peserta di berikan materi yang berhubungan dengan kepemimpinan, sedangkan di hari terahir peserta di berikan 
kesempatan untuk memngaplikasikan materi yang telah di sampaikan dalam kerja bakti yang dimana peserta di bagi menjadi beberapa kelompok dan di tujuk salah satu dari mereka untuk menjadi ketua, disanalah mereka akan belajar bagaimana menjadi seorang pemimpin dan bagaimana menjadi seorang bawahan. Tidak hanya dengan materi dan praktek saja akan tetapi mereka di berikan hiburan atau permainan yang berhubungan dengan kepemimpinan, seperti permainan yuang memacu kekompakan dan kerjasama.

\section{Pengawasan Pelatihan Dasar Kepemimpinan Santri}

Pengawasan merupakan proses pengamatan dari seluruh kegiatan organisasi guna lebih menjamin bahwa semua pekerjaan yang sedang sesuai dengan rencana yang telah di tentukan sebelumnya. Sebagai fungsi organik, pengawasan merupakan salah satu tugas yang mutlak di selenggarakan oleh semua orang yang menduduki jabatan manajerial. Menurut Henry Fayol, pengawasan adalah untuk menunjukan kelemahan-kelemahan dan kesalahan-kesalahan dengan maksud memperbaiki dan mencegah agar tidak terulang kembali. (Sondang P Siagian, 2004: 125).

Pengawasan secara umum dapat di definisikan sebagai cara suatu organisasi mewujudkan kinerja yang efektif dan efisien, serta lebih jauh mendukung terwujudnya visi dan misi organisasi.

Pada dasarnya pengawasan mempunyai kaitan langsung dengan seluruh proses administrasi dan manajemen, pengawasan berkaitan dengan tujuan yang ingin di capai, di laksanakan berdasarkan strategi dasar organisasi yang telah dirumuskan dan di tetapkan, juga pengawasan sangat berkaitan dengan fungsi perencanaan kedua fungsi ini saling mengisi karena; pengawasan harus terlebih dahulu di rencanakan, pengawasan baru dapat dilakukan jika ada rencana, pelaksanaan rencana akan baik, jika pengawasan dilakukan dengan baik, dan tujuan dapat diketahui tercapai dengan baik atau tidak setelah pengawasan atau penilaian dilakukan.

G.R Terry controlling can be defined as the process of determining what is to be accomplished that the standard, what is being accomplished, that is the performance, evaluating the performance take place according to plans, that is, in conformity, with the standard (Pengawasan dapat di definisikan sebagai proses penentuan apa yang harus dicapai yaitu standard apa yang sedang dilakukan yaitu pelaksanaan, menilai pelaksanaan dan apabila perlu dilakukan perbaikan-perbaikan, sehingga pelaksanaan sesuai dengan rencana, yaitu selaras dengan standard) (Irham Fahmi, 2012: 85).

Ketika pelaksanaan kegiatan LDKS pengawasan dilakukan kembali oleh pengarah kegiatan, di lihat bagaimana berlangsungnya acara, dapat berjalan denga baik sesuai yang direncanakan atau ada kendala yang yang dapat menghambat ketika kegiatan berlangsung. Pemngawasan akan terus dilakukan oleh Menteri pendidikan selama kegiatan LDKS ini berlangsung, sehingga pelakasanaan acara inti sampai pada tujuan dan sukses mencetak para santri menjadi calon pemimpin yang berkualitas (Hasil wawancara dengan Presiden OSPAI). 
Telah kita ketahui dalam setiap kegiatan harus ada pengawasan demi berlangsungnya acara sesuai dengan tujuan yang telah di rencanakan pada awal kegiatan, begitupun dengan kegiatan LDKS ini pengawasan sangat di perlukan untuk tercapainya santri dan santriwati yang pandai dan terampil dalam berorganisasi, dan siap berkiprah di masyarakat luas. Dilihat dari semua santri yang berlatar belakang mahasiswa menjadi satu faktor pendukung untuk dilaksanakannya kegiatan LDKS ini.

\section{Evaluasi Pelatihan Dasar Kepemimpinan Santri}

Setelah tersampaikannya semua materi panitia melakukan evaluasi dengan cara simulasi untuk mengetahui sejauh mana peserta memahami materi yang telah disampaikan oleh semua pemateri. Latihan Dasar Kepemimpinan Santri (LDKS) dilaksnakan selama tiga hari, waktu pelaksanaannya dari pukul 07.00-selesai, setiap selesainya acara, ketua pelaksana mengumpulkan panitia dan melakukan evaluasi kegiatan setiap harinya, untuk mengecek kegiatan berjalan sesuai dengan rencana atau tidak, atau ada masalah yang ditemukan ketika kegiatan berlangsung, ketua pelaksana juga akan meminta laporan dari setiap bidang dan menanyakan kendala yang dialami selama pelaksanaan, setelah laporan terkumpul dari setiap bidang lalu ketua pelaksana memberikan laporanya ke pengarah acara, begitu pun hari selanjutnya selalu ada evaluasi yang diberikan oleh ketua pelaksana dan pengarah acara, ketika acara hari demi hari sudah selesai maka tim dari pengarah acara meng evalusi semua kegiatan dari hari pertama sampai hari terakhir, disitu peran pengarah sangat penting karena apa yang di evaluasinya akan menjadi acuan atau referensi untuk kegiatan Latihan Dasar Kepemimpinan Santri berikutnya sehingga tidak terjadi lagi kesalahan yang telah terjadi di kegiatan Latihan Dasar Kepemimpinan Santri sebelumnya (Hasil wawancara dengan Presiden OSPAI).

Jadi setelah semua terlaksana, dari mulai perencanaan hingga pelaksanaan kegiatan LDKS ini maka harus ada evaluasi dari semua pihak, dari mulai panitia pengarah sampai panitia lapangan. Oleh karena itu evaluasi ini menjadi tolak ukur tercapai atau tidaknya tujuan yang telah di rumuskan sejak awal, maka dari itu setelah selelsainya kegiatan LDKS ini selalu diadakan evalusi oleh semua pihak yang bersangkutan dari mulai pengarah hingga panitia pelaksana lapangan untuk mengetahui tercapai atau tidaknya tujuan kegiatan LDKS ini, untuk membuktikan tercapai atau tidaknya tujuan LDKS ini maka dilihat dari laporan pertanggungjawaban seluruh panitia yang berperan dalam kegiatan LDKS.

\section{PENUTUP}

Perencanaan LDKS di atas dapat disimpulkan bahwa setiap bagian dalam kepanitiaan LDKS ini di haruskan untuk bertanggungjawab atas semua tugas yang telah di berikan kepada mereka, untuk mempermudah dalam berlangsungnya acara dan dapat mencapai tujuan yang telah ditentukan sejak awal. Perencanaan dalam kegiatan LDKS ini merupakan tahap awal bagi panitia dalam persiapan 
pelaksanaan LDKS untuk tercapainya tujuan-tujuan di selenggarakannya LDKS ini.

Pengorganisasian pembentukan panitia LDKS ini bahwa semua santri berhak untuk menjadi panitia dalam pelaksanaan LDKS akan tetapi santri yang dipilih untuk menjadi panitia LDKS ini merupakan santri yang aktif dan selalu mengikuti kegiatan yang di selenggarakan di Pondok Pesantren Al-Ihsan. Akan tetapi tidak adil halnya jika panitia hanya di tetntukan atau di pilih oleh menteri pendidikan saja maka di bukalah pengrekrutan untuk menjadi panitia LDKS yang mana bagi setiap santri yang ingin menjadi panitia LDKS bisa mendaftar kepada staf kementrian pendidikan dan harus memenuhi syarat-syarat yang telah di tentukan.

Pelaksanaan LDKS ini dapat kita lihat bahwa kegiatan ini merupakan program tahunan yang wajib diikuti oleh setiap santri baru untuk pengkaderan pemimpin atau untuk menyiapkan santri dan santriwati yang siap menjadi pemimpin di kemudian hari, dengan waktu pelaksanaannya selama tiga hari dan dalam tiga hari tersebut dua hari pertama peserta di berikan materi yang berhubungan dengan kepemimpinan, sedangkan di hari terahir peserta di berikan kesempatan untuk memngaplikasikan materi yang telah di sampaikan dalam kerja bakti yang dimana peserta di bagi menjadi beberapa kelompok dan di tujuk salah satu dari mereka untuk menjadi ketua, disanalah mereka akan belajar bagaimana menjadi seorang pemimpin dan bagaimana menjadi seorang bawahan. Tidak hanya dengan materi dan praktek saja akan tetapi mereka di berikan hiburan atau permainan yang berhubungan dengan kepemimpinan, seperti permainan yuang memacu kekompakan dan kerjasama.

Telah kita ketahui dalam setiap kegiatan harus ada pengawasan demi berlangsungnya acara sesuai dengan tujuan yang telah di rencanakan pada awal kegiatan, begitupun dengan kegiatan LDKS ini pengawasan sangat di perlukan untuk tercapainya santri dan santriwati yang pandai dan terampil dalam berorganisasi, dan siap berkiprah di masyarakat luas. Dilihat dari semua santri yang berlatar belakang mahasiswa menjadi satu faktor pendukung untuk dilaksanakannya kegiatan LDKS ini. Setelah semua terlaksana, dari mulai perencanaan hingga pelaksanaan kegiatan LDKS ini maka harus ada evaluasi dari semua pihak, dari mulai panitia pengarah sampai panitia lapangan.

Setelah semua terlaksana, dari mulai perencanaan hingga pelaksanaan kegiatan LDKS ini maka harus ada evaluasi dari semua pihak, dari mulai panitia pengarah sampai panitia lapangan. Oleh karena itu evaluasi ini menjadi tolak ukur tercapai atau tidaknya tujuan yang telah di rumuskan sejak awal, maka dari itu setelah selelsainya kegiatan LDKS ini selalu diadakan evalusi oleh semua pihak yang bersangkutan dari mulai pengarah hingga panitia pelaksana lapangan untuk mengetahui tercapai atau tidaknya tujuan kegiatan LDKS ini, untuk membuktikan tercapai atau tidaknya tujuan LDKS ini maka dilihat dari laporan pertanggungjawaban seluruh panitia yang berperan dalam kegiatan LDKS. 


\section{DAFTAR PUSTAKA}

Aep Kusnawan dan Aep Sy Firdaus, 2009, Manajemen Pelatihan Dakwah, Rineka Cipta, Jakarta,

Ahmad Ibrahim Abu Sinn, , 2012 Manajemen Syariah sebuah kajian historis dan kontemporer, Fajar Interpratama Ofset, Jakarta.

Brantas, Dasar-Dasar Manajemen, 2009 Alfabeta,Bandung,.

Dewi Sadiah, 2014 Metode Penelitian Dakwah Pendekatan Kualitatif Dan Kuantitatif, mimbar pustaka, Bandung,

Endin Nasrudin, 2010, Psikologi Manajemen, pustaka setia, Bandung,.

George R.Terry dan Winardi, 1986 Asas-Asas Manajemen, Alumni, Bandung.

Hadari Nawawi, 2006 Kepemimpinan Mengefektifkean Organisasi, Gadjah Mada University Press, Yogyakarta.

Irham Fahmi, 2012 Manajemen Teori Kasus dan Solusi, Alfabeta, Bandung,.

Jamal Lulail Yunus, 2009 Leadership Model, UIN Malang press, Malang,.

Jhon Adair, 1993, Membina Calon Pemimpin, Bumi Aksara, Jakarta,.

Malayu S.P Hasibuan, 2001, Manajemen Dasar Pengertian Dan Masalah, Bumi Aksara, Jakarta,.

Mar'at, 1984, Pemimpin dan Kepemimpinan, Ghalia Indonesia, Jakarta,.

M. Munir dan wahyu Ilaihi. 2006, Manajemen Dakwah, kencana, Jakarta,.

Meldona. 2009, Manajemen Sumber Daya Manusia, UIN Malang press, Malang,.

M. Karjadi, 1989, Kepemimpinan, Karya Nusantara, Bandung,.

Sutarto, 1998, Dasar-Dasar Kepemimpinan Administrasi, Gadjah Mada University Press, Yogyakarta.

Sondang P. Siagian, 2004, Fungsi-Fungsi Manajerial, Bumi Aksara, Jakarta,.

Sondang P. Siagian, 2010, Teori dan Praktek kepemimpinan, PT Rineka Cipta, Jakarta,.

Veithzal Rivai. 2008, Kepmimpinan Dan Perilaku Organisasi, PT Raja Grafindo Persada, Jakarta. 